\title{
PARASITOLOGICAL SURVEYS IN THE JOS PLATEAU, NIGERIA
}

\author{
Kuninori Shiwaku ${ }^{1}$, Hiroshi Takahashi ${ }^{2}$, Bertram E. B. NwokE ${ }^{3}$, \\ Celestine O. E. OnwUliri and Gad O. Ufomadu ${ }^{3}$ \\ Received July 14 1986/Accepted November 101986
}

\begin{abstract}
Surveys for schistosomiasis, intestinal parasitic infections and filariasis were carried out in 3 villages of the Jos Plateau, Nigeria, in the period between February and March, 1985. Of 668 fecal samples, $66.8 \%$ were found to harbour parasitic eggs and protozoa. The overall prevalence of parasitic infections among villagers was as follows: hookworm, $40.3 \%$; Ascaris lumbricoides, 9.1\%; Strongyloides stercoralis, 0.3\%; Trichuris trichiura, 0.4\%; Schistosoma mansoni, 18.9\%; Taenia sp., 0.1\%; Hymenolepis nana, 0.1\%; and cysts of Entamoeba histolytica, 6.7\%; Entamoeba coli, 31.4\%; Iodamoeba bütschlii, 11.1\%; Endolimax nana, 2.5\%; Chilomastix mesnili, 1.6\%; Giardia lamblia, 1.5\%. Hookworm was the predominant helminth, and the infective larvae of Necator americanus were found in 6 pupils using filter paper-cultures. The prevalence rates of hookworm infection varied significantly with villages; $53.9 \%$ at Sop, $33.3 \%$ at Jebu and $6.0 \%$ at Maigemu. Of the 344 inhabitants, $5.2 \%$ and $13.4 \%$ were found to harbour microfilariae of Loa loa and Dipetalonema perstans, respectively. Factors which may have contributed to the spread of these parasitic infections on the Jos Plateau are discussed.
\end{abstract}

\section{INTRODUCTION}

Nearly half of the people in Nigeria are living in the rural areas, and are engaging in farming. Water supply, sewage and refuse disposal are poorly organized in the rural areas. The villagers usually defecate directly on the ground. Propagations of helminths and protozoa are therefore facilitated by this practice. A report on the stool examination for ova and cysts by Azikiwe (1984) was the only available one on the parasitological situation in the Jos Plateau. He reported that hookworm and $A$. lumblicoides were the most common parasitic infestation, and $T$. trichiura, E. coli, S. stercoralis, S. mansoni and G. lamblia were found in 190 employees and their family members and 47 students of the University of Jos.

Between February and March, 1985, the inhabitans in 3 villages of the Jos Plateau were surveyed for filarial infections, schistosomiasis and intestinal parasitic infections with the aim of providing base line parasitological data.

This study was supported by the JICA, Japan-Jos University, Nigeria Project (JUJIP-No. 04)

1 Department of Parasitology, Aichi Medical University, Yazako, Nagakute-cho, Aichi-gun, Aichi 480-11, Japan

2 The Japan International Cooperation Agency, University of Jos, Jos, Plateau State, Nigeria

3 Department of Zoology, Faculty of Natural Science, University of Jos, Jos, Plateau State, Nigeria

4 Parasitological Division, Nigerian Institute for Trypanosomiasis Research, Vom, Plateau State, Nigeria 


\section{Materials and Methods}

Study areas: The Jos Plateau is located in the central part of Nigeria, approximately 104 $\mathrm{km}$ from north to south, and $80 \mathrm{~km}$ from east to west. It rises steeply in the south-west by a $600 \mathrm{~m}$ scarp from a height of $750 \mathrm{~m}$ to a height of over $1,300 \mathrm{~m}$ above sea level. Most parts of the Plateau lie on this elevation except the Shere Hills which rise to heights of over $1,800 \mathrm{~m}$ (Figure 1). The vegetation of the Jos Plateau is the typical northern Guinea savanna. In Jos $94 \%$ of the rains fell within the 6 wet months of April to September in 1984. There was no rainfall between November and February during which period the relative humidity was low. The temperature varied between 12 and $32^{\circ} \mathrm{C}$. The hottest month was March, and coincides roughly with the passage of the sun overhead. Two periods of low temperatures were re-

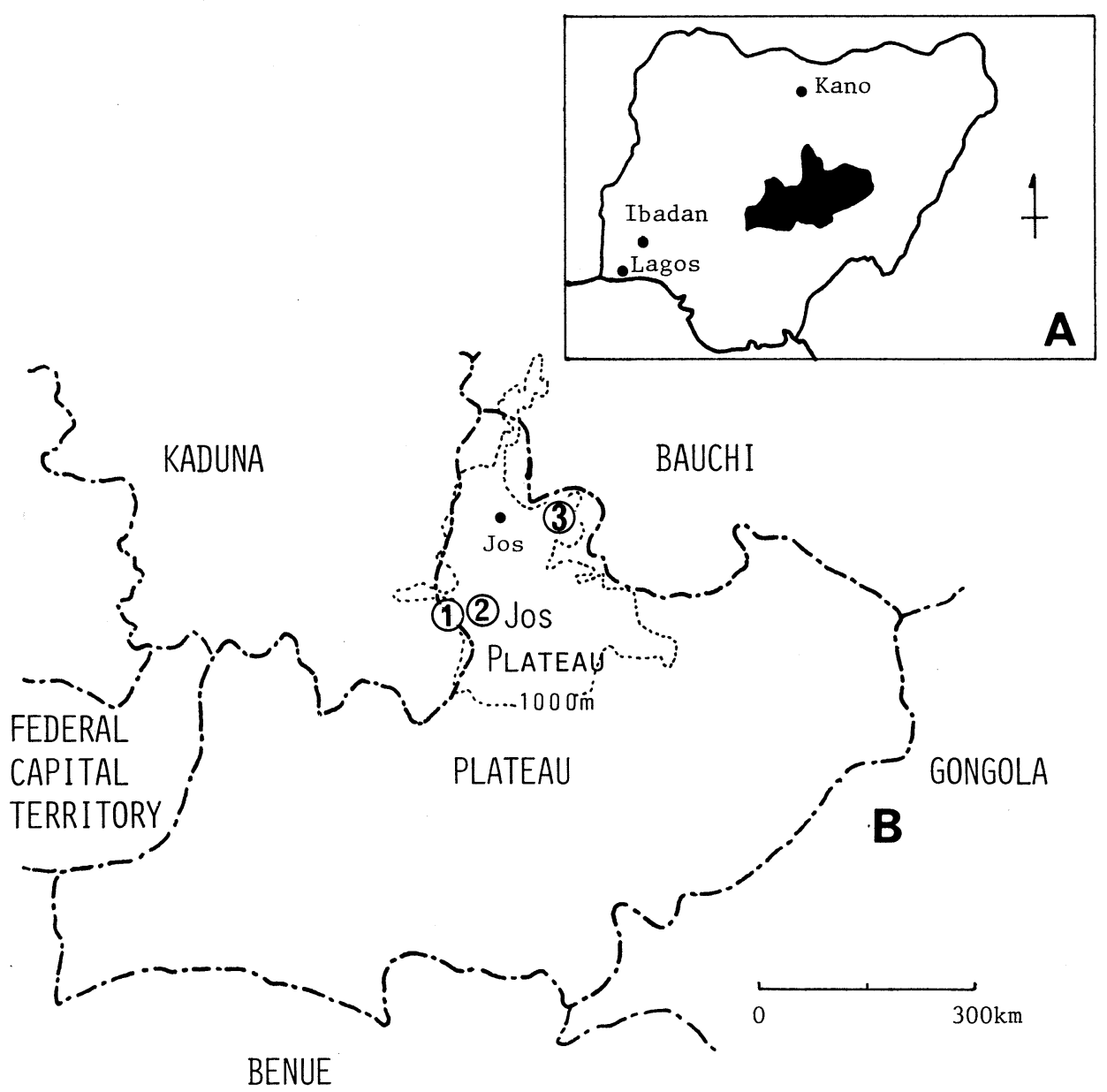

Figure 1 A: Map showing the location of Plateau State (black portion) in Nigeria.

B: Map showing 3 villages examined in the Jos Plateau.

(1): Sop, (2): Jebu, (3): Maigemu 
corded. The first occurs in the middle of the wet season; the second coolest period occurs in the middle of the dry season as a result of the cool north-east hamattarn wind from the Sahara Desert.

Three villages were selected for parasitological surveys on the Jos Plateau (Figure 1). Sop and Jebu lie within the Bauchi Local Government area in the south along the bank of the river Assob at a height of $800 \mathrm{~m}$. These 2 villages are close to each other and the river Assob is the perennial one. Sop has many springs and Jebu, an irrigation canal. Maigemu lies within the Jos Local Government area in the north along the bank of the river Jarawa at a height of $720 \mathrm{~m}$. The tributary of the river Jarawa near Maigemu is seasonal, and there are only some muddy puddles in the dry season. The inhabitants of these 3 villages are consisted of the Jarawa, Hausa and a small number of the Fulani people.

Fecal examination: The stool samples were collected in plastic containers which were distributed to the villagers and retrieved in the next morning. Samples were preserved in $10 \%$ formalin solution, and were examined after formalin-ether centrifugation technique (MGL method) by light microscopy. Filter paper-culture method was applied for fecal samples from 6 pupils at Sop to identify the species of hookworm.

Blood examination: Blood samples were taken from the finger tip at Sop and Jebu, and by veni-puncture at Maigemu during the time from 10 a.m. to 4 p.m. Thick films were prepared, dried overnight, dehemoglobinized, fixed by absolute methyl alcohol and stained with Giemsa.

Statistical analysis of the results: Statistical differences of parasite infections in 3 villages were assessed by ANOVA among the inhabitants aged 10 years old and more, as no subject below 9 years old was examined at Maigemu.

\section{RESULTS}

A total of 668 fecal samples of the inhabitants from 3 villages were examined and 446 $(66.8 \%)$ were found to harbour parasites. The prevalence of parasitic infections was $72.8 \%$ at Sop, $55.7 \%$ at Jebu and $69.0 \%$ at Maigemu, respectively. The overall infection rate of people with individual parasites were shown in Table 1. Hookworm was the most prevalent intestinal helminth. As indicated in Table 2, the infection rate of hookworm was the highest at Sop $(53.9 \%)$ and the lowest at Maigemu (6.0\%). Differences in the prevalence of hookworm infection among the inhabitants at Sop, Jebu and Maigemu varied significantly $(\mathrm{p}<0.001)$ with villages. There was no significant difference in prevalence of hookworm between males and females. Prevalence of hookworm infection at Sop was high in subjects of 10-29 years old, and low in 30 years old and more. The infective larvae of $N$. americanus were identified in all the 6 pupils at Sop using filter paper-cultures.

Table 3 demonstrates the prevalence of $S$. mansoni infection by age groups at the 3 villages. Eggs of S. mansoni were found in $32.9 \%$ at Sop and $4.7 \%$ at Jebu, but not at Maigemu. There were significant differences in the prevalence of $S$. mansoni infection in 3 villagers over 10 years old $(\mathrm{p}<0.01)$ with villages. The high prevalence rate of $S$. mansoni at Sop was observed in the age group of $10-19$ years old and was significantly lower in adults over 20 years old $(p<0.005)$. The highest infection rate was $61.9 \%$ in the age group of $10-19$ years old at Sop. Twenty-four children below 3 years old examined were negative for the eggs of $S$. mansoni.

The overall prevalence of $E$. histolytica cyst was $6.7 \% ; 6.2 \%$ at Sop, $6.6 \%$ at Jebu and $9.0 \%$ at Maigemu, with a peak in the age group of 10-19 years old. E. coli were the most common 
Table 1 Prevalence of parasitic infections using formalin-ether centrifugation technique arranged by village

\begin{tabular}{|c|c|c|c|c|}
\hline Village & Sop & Jebu & Maigemu & Total \\
\hline $\begin{array}{l}\text { Number } \\
\text { examined }\end{array}$ & 356 & 213 & 100 & 668 \\
\hline hookworm & $\begin{array}{c}192 \\
(53.9)\end{array}$ & $\begin{array}{c}71 \\
(33.3)\end{array}$ & $\begin{array}{c}6 \\
(6.0)\end{array}$ & $\begin{array}{c}269 \\
(40.3)\end{array}$ \\
\hline A. lumblicoides & $\begin{array}{c}19 \\
(5.3)\end{array}$ & $\begin{array}{c}42 \\
(19.7)\end{array}$ & 0 & $\begin{array}{c}61 \\
(9.1)\end{array}$ \\
\hline S. stercoralis & $\begin{array}{c}2 \\
(0.6)\end{array}$ & 0 & 0 & $\begin{array}{c}2 \\
(0.3)\end{array}$ \\
\hline T. trichiura & $\begin{array}{c}1 \\
(0.3)\end{array}$ & $\begin{array}{c}2 \\
(0.9)\end{array}$ & 0 & $\begin{array}{c}3 \\
(0.4)\end{array}$ \\
\hline S. mansoni & $\begin{array}{c}116 \\
(32.6)\end{array}$ & $\begin{array}{l}10 \\
(4.7)\end{array}$ & 0 & $\begin{array}{c}126 \\
(18.9)\end{array}$ \\
\hline Taenia sp. & $\begin{array}{c}1 \\
(0.3)\end{array}$ & 0 & 0 & $\begin{array}{c}1 \\
(0.1)\end{array}$ \\
\hline H. nana & 0 & $\begin{array}{c}1 \\
(0.5)\end{array}$ & 0 & $\begin{array}{c}1 \\
(0.1)\end{array}$ \\
\hline E. histolytica & $\begin{array}{c}22 \\
(6.2)\end{array}$ & $\begin{array}{l}14 \\
(6.6)\end{array}$ & $\begin{array}{c}9 \\
(9.0)\end{array}$ & $\begin{array}{c}45 \\
(6.7)\end{array}$ \\
\hline E. coli & $\begin{array}{c}90 \\
(25.3)\end{array}$ & $\begin{array}{c}56 \\
(26.3)\end{array}$ & $\begin{array}{c}64 \\
(64.0)\end{array}$ & $\begin{array}{c}210 \\
(31.4)\end{array}$ \\
\hline I. bütschlii & $\begin{array}{c}41 \\
(11.5)\end{array}$ & $\begin{array}{l}20 \\
(9.4)\end{array}$ & $\begin{array}{c}13 \\
(13.0)\end{array}$ & $\begin{array}{c}74 \\
(11.1)\end{array}$ \\
\hline E. nana & $\begin{array}{c}14 \\
(3.9)\end{array}$ & $\begin{array}{c}2 \\
(0.9)\end{array}$ & $\begin{array}{c}1 \\
(1.0)\end{array}$ & $\begin{array}{c}17 \\
(2.5)\end{array}$ \\
\hline C. mesnili & $\begin{array}{c}4 \\
(1.1)\end{array}$ & $\begin{array}{c}4 \\
(1.9)\end{array}$ & $\begin{array}{c}3 \\
(3.0)\end{array}$ & $\begin{array}{c}11 \\
(1.6)\end{array}$ \\
\hline G. lamblia & $\begin{array}{c}5 \\
(1.4)\end{array}$ & $\begin{array}{c}5 \\
(2.3)\end{array}$ & 0 & $\begin{array}{c}10 \\
(1.5)\end{array}$ \\
\hline
\end{tabular}

Numbers in parentheses are percentage.

Table 2 Prevalence of hookworm infection by age

\begin{tabular}{ccccccc}
\hline & \multicolumn{2}{c}{ Sop } & \multicolumn{2}{c}{ Jebu } & \multicolumn{2}{c}{ Maigemu } \\
$\begin{array}{c}\text { Age } \\
\text { group }\end{array}$ & $\begin{array}{c}\text { Number } \\
\text { examined }\end{array}$ & $\begin{array}{c}\text { Number } \\
\text { infected }\end{array}$ & $\begin{array}{c}\text { Number } \\
\text { examined }\end{array}$ & $\begin{array}{c}\text { Number } \\
\text { infected }\end{array}$ & $\begin{array}{c}\text { Number } \\
\text { examined }\end{array}$ & $\begin{array}{c}\text { Number } \\
\text { infected }\end{array}$ \\
\hline $0-9$ & 157 & $67(42.7)$ & 101 & $19(18.8)$ & 0 & - \\
$10-19$ & 113 & $84(74.3)$ & 46 & $26(29.7)$ & 11 & $1(9.1)$ \\
$20-29$ & 32 & $21(65.6)$ & 29 & $11(37.9)$ & 15 & $1(6.7)$ \\
$30-39$ & 25 & $6(24.0)$ & 21 & $11(52.4)$ & 31 & $3(9.7)$ \\
over 40 & 29 & $14(48.3)$ & 16 & $4(25.0)$ & 43 & $1(2.3)$ \\
\hline Total & 356 & $192(53.9)$ & 213 & $71(33.3)$ & 100 & $6(6.0)$ \\
\hline
\end{tabular}

Numbers in parentheses are percentage. 
Table 3 Prevalence of Schistosoma mansoni infection by age

\begin{tabular}{|c|c|c|c|c|c|c|}
\hline \multirow[b]{2}{*}{$\begin{array}{l}\text { Age } \\
\text { group }\end{array}$} & \multicolumn{2}{|c|}{ Sop } & \multicolumn{2}{|c|}{ Jebu } & \multicolumn{2}{|c|}{ Maigemu } \\
\hline & $\begin{array}{l}\text { Number } \\
\text { examined }\end{array}$ & $\begin{array}{l}\text { Number } \\
\text { infected }\end{array}$ & $\begin{array}{l}\text { Number } \\
\text { examined }\end{array}$ & $\begin{array}{l}\text { Number } \\
\text { infected }\end{array}$ & $\begin{array}{l}\text { Number } \\
\text { examined }\end{array}$ & $\begin{array}{l}\text { Number } \\
\text { infected }\end{array}$ \\
\hline $0-9$ & 157 & $38(24.2)$ & 101 & 0 & 0 & - \\
\hline $10-19$ & 113 & $70(62.0)$ & 46 & $4(8.7)$ & 11 & 0 \\
\hline $20-29$ & 32 & $3(9.4)$ & 29 & $4(13.8)$ & 15 & 0 \\
\hline $30-39$ & 25 & $4(16.0)$ & 21 & $1(3.7)$ & 31 & 0 \\
\hline over 40 & 29 & $1 \quad(3.5)$ & 16 & $1(6.3)$ & 43 & 0 \\
\hline Total & 356 & $116(32.6)$ & 213 & $10(4.7)$ & 100 & 0 \\
\hline
\end{tabular}

Numbers in parentheses are percentage.

Table 4 Prevalence of Loa loa and Dipetalonema perstans infections by age

\begin{tabular}{ccccccccccc}
\hline & \multicolumn{3}{c}{ Sop } & \multicolumn{4}{c}{ Jebu } & \multicolumn{4}{c}{ Maigemu } \\
$\begin{array}{c}\text { Age } \\
\text { group }\end{array}$ & $\begin{array}{c}\text { Number } \\
\text { examined }\end{array}$ & L. loa & D. perstans & $\begin{array}{c}\text { Number } \\
\text { examined }\end{array}$ & L. loa & D. perstans & $\begin{array}{c}\text { Number } \\
\text { examined }\end{array}$ & L. loa & D. perstans \\
\hline $0-9$ & 4 & 0 & 0 & 2 & 0 & 0 & 0 & - & - \\
$10-19$ & 34 & 0 & $5(14.7)$ & 32 & 0 & $9(11.6)$ & 15 & 1 & $(6.7)$ & 0 \\
$20-29$ & 32 & $1(3.1)$ & $6(18.8)$ & 26 & $1(3.9)$ & $3(11.6)$ & 18 & $1(5.6)$ & $1(5.6)$ \\
$30-39$ & 25 & 0 & $6(24.0)$ & 23 & 0 & 1 & $(4.3)$ & 34 & $5(14.7)$ & $1(2.9)$ \\
over 40 & 28 & 0 & $12(42.9)$ & 18 & $1(5.6)$ & 0 & 53 & $8(15.1)$ & $2(3.8)$ \\
\hline Total & 123 & $1(0.8)$ & $29(23.6)$ & 101 & $2(2.0)$ & $13(12.9)$ & 120 & $15(12.5)$ & $4(3.3)$ \\
\hline
\end{tabular}

Numbers in parentheses are percentage.

intestinal protozoa showing overall infection rate of $31.4 \%$. The infection rate of E. coli at Maigemu was significantly higher than those at Sop and Jebu in age groups of over 10 years old $(\mathrm{p}<0.005)$.

Blood examination was mainly carried out on adults because of the ease in collecting blood and the lack of manpower to cope with the large number (Table 4). At Sop and Jebu, 1.3\% of blood sampled showed L. loa microfilariae and $18.8 \%$ revealed D. perstans. At Maigemu, $12.5 \%$ of the inhabitants examined were positive for L. loa microfilariae and $3.3 \%$ for D. perstans. The prevalence of $L$. loa at Maigemu was significantly higher than that at Sop and Jebu $(\mathrm{p}<0.05)$. The infection rate of $D$. perstans at Sop and Jebu was significantly higher than that Maigemu $(\mathrm{p}<0.005)$. The microfilarial density ranged between 1 and 72 microfilariae (mean value 6.3) for $L$. loa and between 1 and 8 microfilariae (mean value 1.5) for D. perstans in about $30 \mathrm{~mm}^{3}$ blood at the study areas.

\section{Discussion}

Hookworm was the predominant helminth in the 3 villages of the Jos Plateau. Some reports have shown that 2 species of human hookworm, N. americanus and Ancylostoma duodenale, are seen in several parts of Nigeria (Nwosu and Anya, 1980; Udonsi, 1984). It seems 
that $N$. americanus is common on the Jos Plateau as the infective larvae of $N$. americanus were identified in all of 6 pupils using filter paper-cultures.

In Jos, temperatures are consistently above the $10^{\circ} \mathrm{C}$ ambient, which is the minimum temperature for hookworm development (Nwosu, 1978a). Temperature may therefore have little effect on the build-up of hookworm infection in these areas. Precipitation, on the other hand, tends to have a marked seasonal pattern. As the free-living stages of hookworms are highly susceptible to desiccation (Nwosu, 1978b), low humidity in the soil would tend to reduce transmission of hookworm. Even in the dry season, there are usually many springs and streams at Sop, thus supporting a highest infection rate of hookworm; conversely, the seasonality in the tributary of the river Jarawa at Maigemu, probably explains the lower prevalence observed. Accordingly, it seems that the differences in the prevalence of hookworm among 3 villages are attributable to the differences in the humidity of soil in the dry season.

S. mansoni and S. haematobium are widely distributed in Nigeria (Cowper, 1963; Kaneko and Odiachi, 1976; Pugh and Gilles, 1978; Hori and Odiachi, 1978). A lot of B. pfeifferi were found in the springs and streams at Sop and the irrigation canal at Jebu. Snails collected from Jebu had the fork-tailed cercariae which are the characteristic of Schistosomatoidea. The inhabitants were probably infected at Sop and Jebu while bathing or wading in the springs, streams and irrigation canal. Recently, the spread of schistosomiasis has been fostered by increased irrigation (WHO, 1980). It must be emphasized that adequate measures for schistosomiasis control should be made an integral part of water resource development projects.

S. mansoni infection at Sop increased with age, attained a peak at 10-19 years old and declined at 20 years old or older. The reason for this reduction of prevalence remain uncertain; but accumulating evidences suggest different mechanisms such as an immune mechanism and reduced water contact in the adults (Jordan and Webbe, 1982).

A survey of intestinal protozoan infections in Nigeria was performed on a large scale by Ogunba (1977) who collected stool samples from an Ibadan population including 3,400 children and 621 adults. Prevalence of E. histlytica, E. nana and C. mesnili were lower in the present study area than those in Ibadan, and prevalence of E. coli, I. bütchlii and G. lamblia were higher in the present area than those in Ibadan. It seems that these differences in prevalence of intestinal protozoa infections are due to the differences in the climate and social environment between the present area and Ibadan.

Recently, Hori and Odiachi (1978) and Hori et al. (1984) carried out surveys on loiasis in the southwestern region of Nigeria in which the infection rates of 3.8-28.9\% were reported. In the present surveys it is evident that the Jos Plateau is endemic area for loiasis. Using thick smears, Wijiyiratne et al. (1982) reported the prevalence of $D$. perstans infection of $2.6 \%$ in a village in the Malunfashi district of Kadona State which shares borders with Plateau State. Prevalence of $D$. perstans infection at the present study villages was higher than that reported by Wijiyiratne et al.

\section{ACKNOWLEDGEMENTS}

We wish to thank Prof. Rokuro Kano, President of Tokyo Medical and Dental University, and Prof. M. O. E. Iwuala, Dean of Postgraduate School, University of Jos, for their encouragement throughout the present study. Thanks are also due to Prof. Kiyotoshi Kaneko, Aichi Medical University for reading the manuscript. 


\section{REFERENCES}

1) Azikiwe, A. N. (1984): Prevalence and pattern of intestinal infections in an African university community, Ann. Trop. Med. Parasit., 78 (3), 333-334

2) Cowper, S. G. (1963): Schistosomiasis in Nigeria. Ann. Trop. Med. Parasit., 57, 307-314

3) Hori, E., Amano, T., Takaoka, M., Inaoka, T., Watanabe, M., Yamaguchi, K. and Ogunba, E. O. (1984): Epidemiological studies on loiasis in Nigeria (2) surveys of microfilaria in Epe and surveys of the vectors, Chrysops, J. Saitama Med. School, 11 (2), 121-130 (In Japanese)

4) Hori, E. and Odiachi, G. U. (1978): A survey of parasitic helminths and protozoa in Ife, Nigeria, J. Saitama Med. School, 5, 143-150 (in Japanese)

5) Jordan, P. and Webbe, G. (1982): Schistosomiasis; epidemiology, treatment and control, 227-292, William Heinmann Medical Books LTD., London

6) Kaneko, K. and Odiachi, G. U. (1976): Parasitological survey in Ife, Western State of Nigeria, J. Aichi Med. Univ. Assoc., 4 (2), 113-118 (In Japanese)

7) Nwosu, A. B. C. (1978a): Investigations into the free-living phase of the cat hookworm life cycle, $Z$. Parasitenkd., 56, 243-249

8) Nwosu, A. B. C. (1978b): Desiccation-survial of the eggs and third stage larvae of hookworms, Bull. Anim. Hith. Prod. Afr., 25, 73-78

9) Nwosu, A. B. C. and Anya, A. O. (1980): Seasonality in human hookworm infections in an endemic area of Nigeria, and its relationship to rainfall, Tropenmed. Parasit., 31, 201-208

10) Ogunba, E. O. (1977): The prevalence of human intestinal protozoa in Ibadan, Nigeria, J. Trop. Med. Hyg., 80, 187-191

11) Pugh, R. N. H. and Gilles, H. M. (1978): Malumafashi endemic diseases research project, III. Urinary schistosomiasis: A longitudinal study, Ann. Trop. Med. Parasit., 72, 471-482

12) Udonsi, J. K. (1984): Studies on the co-occurrence of two species of human hookworm in a riverine community in Nigeria, Tropenmed. Parasit., 35 (1), 37-40

13) Wijeyaratne, P. M., Singha, P., Verama, O. P. and Motha, B. (1982): Evaluation of the diethylcarbamazine provocative test in the diagnosis of Wuchereria bancrofti infections in the Nigerian savanna and the effects on Dipetalonema perstans, Trans. R. Soc. Trop. Med. Hyg., 76 (3), 387-391

14) World Health Organization (1980): Epidemiology and control of schistosomiasis, 18-23, WHO Technical Report Series, No. 643, Geneva 


\title{
ナイジェリア連邦共和国，ジョス高地における寄生虫調査
}

\author{
塩飽 邦憲 ${ }^{1} \cdot$ 高橋 弘 $^{2} \cdot$ B. E. B. Nwoke ${ }^{3}$
}

C. O. E. Onwuliri ${ }^{3}$ - G. O. Ufomadu ${ }^{4}$

昭和 61 年 7 月 14 日 受付/昭和 61 年 11 月 10 日 受理

ナイジェリア，ジョス高地の 3 農村の住民を対象として1985年 2-3 月の期間に，粪便検査によって 腸管寄生蠕虫類・原虫類およびマンソン住血吸虫の検出を, 血液厚層塗抹検査により糸状虫ミクロ フィラリアの検出を行った。その結果，糞便検査を行った668名の住民のうち，66.8\%に何らかの腸管 寄生虫㧍よびマンソン住血吸虫の寄生を認め, 寄生率は銁虫 $40.3 \%$, 回虫 $9.1 \%$, 糞線虫 $0.3 \%$, 鞭虫 $0.4 \%$ ，マンソン住血吸虫 $18.9 \%$, Taenia sp. $0.1 \%$ ，小形条虫 $0.1 \%$ ，赤痢アメーバ $6.7 \%$ ，大腸ア

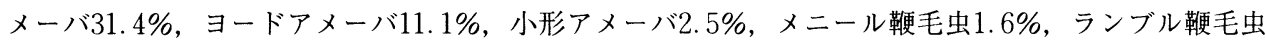
$1.5 \%$ あった。6 名の児童について翼便の滤紙培養検査を行い, 全てアメリカ銁虫の感染幼虫と同定 した。銁虫の感染率は，調査した 3 村で Sop 53.9\%，Jebu 33.3\%， Maigemu 6.0\%と有意な差が認め られた $(\mathrm{p}<0.001)$ 。334名の住民について血液厚層塗抹検査を行い，5.2\%の住民よりロア糸状虫ミク ロフィラリアを，13.4\%より常在系状虫ミクロフィラリアを検出した。ジョス高地に扔けるこれらの 寄生虫疾患の分布を規定する要因について, 若干の考察を行った。

1 愛知医科大学寄生虫学教室 2 国際協力事業団, ジョス大学医学部 3 ジョス大学理学部動物 学教室 4 ナイジェリア・トリパノソーマ症研究所

この研究は日本-ナイジェリア医学協力事業によった (JUJIP-No. 04)。 